\title{
Role of Cytochrome P-450 in Reperfusion Injury of the Rabbit Lung
}

Gokol Kris Bysani, Thomas P. Kennedy, Nguyet Ky, N. V. Rao, Cheryl A. Blaze, and John R. Hoidal

Divisions of Pediatric Critical Care, the University of Tennessee, Memphis, and St. Jude Children's Research Hospital, Memphis,

Tennessee 38152; the Division of Allergy, Critical Care, and Respiratory Medicine, Duke University Medical Center, Durham,

North Carolina 27710; and the Division of Respiratory Medicine, University of Utah, Salt Lake City, Utah 84112

\section{Abstract}

Reactive oxygen species are a major cause of damage occurring in ischemic tissue after reperfusion. During reperfusion transitional metals such as iron are required for reactive oxygen species to mediate their major toxic effects. Xanthine oxidase is an important source of reactive oxygen species during ischemia-reperfusion injury, but not in all organs or species. Because cytochrome $\mathbf{P}-\mathbf{4 5 0}$ enzymes are an important pulmonary source of superoxide anion $\left(\mathrm{O}_{\bar{i}}^{\overline{ }}\right)$ generation under basal conditions and during hyperoxia, and provide iron catalysts necessary for hydroxyl radical ('OH) formation and propagation of lipid peroxidation, we postulated that cytochrome $\mathrm{P}-\mathbf{4 5 0}$ might have a potential role in mediating ischemia-reperfusion injury. In this report, we explored the role of cytochrome $P-450$ enzymes in a rabbit model of reperfusion lung injury. The $\mathbf{P}-\mathbf{4 5 0}$ inhibitors 8-methoxypsoralen, piperonyl butoxide, and cimetidine markedly decreased lung edema from transvascular fluid flux. Cimetidine prevented the reperfusion-related increase in lung microvascular permeability, as measured by movement of ${ }^{125}$ I-albumin from the vascular space into lung water and alveolar fluid. $\mathbf{P}-\mathbf{4 5 0}$ inhibitors also prevented the increase in lung tissue levels of thiobarbituric acid reactive products in the model. $P-450$ inhibitors did not block enhanced $O_{\bar{i}}^{-}$generation by ischemic reperfused lungs, measured by in vivo reduction of succinylated ferricytochrome $c$ in lung perfusate, but did prevent the increase in non-protein-bound low molecular weight chelates of iron after reperfusion. Thus, cytochrome $\mathbf{P}-\mathbf{4 5 0}$ enzymes are not likely a major source of enhanced $O_{\bar{i}}$ generation, but serve as an important source of iron in mediating oxidant injury to the rabbit lung during reperfusion. These results suggest an important role of cytochrome $P-450$ in reperfusion injury to the lung and suggest potential new therapies for the disorder. (J. Clin. Invest. 1990. 86:1434-1441.) Key words: reperfusion lung injury $\bullet$ cytochrome $P-450 \cdot$ cimetidine $\bullet$ reactive oxygen species

\section{Introduction}

Oxidant damage from generation of superoxide anions $\left(\mathrm{O}_{\overline{2}}^{\overline{2}}\right)^{1}$ and hydrogen peroxide $\left(\mathrm{H}_{2} \mathrm{O}_{2}\right)$ during reperfusion of ischemic

Address reprint requests to Dr. Kennedy, Division of Allergy, Critical Care and Respiratory Medicine, Box 3177, Duke University Medical Center, Durham, NC 27710.

Received for publication 9 June 1989 and in revised form 16 May 1990.

1. Abbreviations used in this paper: $\mathrm{C}$, cimetidine; $\mathrm{C}_{\mathrm{dyn}}$, dynamic lung compliance; MDA, malondialdehyde; 8-MP, 8-methoxypsoralen; $\mathrm{O}_{\overline{2}}$,

J. Clin. Invest.

(C) The American Society for Clinical Investigation, Inc.

0021-9738/90/11/1434/08 $\$ 2.00$

Volume 86, November 1990, 1434-1441 tissue is now a well documented mechanism of injury (1). One important source of $\mathrm{O}_{\dot{2}}$ and $\mathrm{H}_{2} \mathrm{O}_{2}$ during reperfusion is xanthine oxidase (1). However, recent studies indicate that xanthine oxidase is not the major source of $\mathrm{O}_{\overline{2}}^{\overline{2}}$ and $\mathrm{H}_{2} \mathrm{O}_{2}$ production in all organs or species (2-5).

Another cellular site for generation of reactive oxygen species is microsomal electron transport, which produces $\mathrm{O}_{\overline{2}}$ during oxidative metabolism at the cytochrome P-450 complex $(6,7)$ and/or during the oxidation of NADPH by cytochrome $c$ $(P-450)$ reductase $(8,9)$. Lung, like liver, is richly endowed with cytochrome $\mathrm{P}-450$ (10). These microsomal enzymes are a major source of the $\mathrm{O}_{\overline{2}}^{\overline{2}}$ and $\mathrm{H}_{2} \mathrm{O}_{2}$ generated by lung under basal conditions (11) and during hyperoxia $(12,13)$. Cytochrome P-450 enzymes may also participate in reperfusion injury by providing an intracellular source of iron. In reperfusion injury iron appears to promote tissue damage by catalyzing hydroxyl radical ( $\left.{ }^{\circ} \mathrm{OH}\right)$ generation via the Fenton reaction and by propagating lipid peroxidation. Recently, the iron chelator deferoxamine has been shown to prevent reperfusion injury in the heart (14), intestine (15), skin (16), brain (17), and lung (18). While much activity has been directed toward defining the source of $\mathrm{O}_{\overline{2}}^{\overline{2}}$ and $\mathrm{H}_{2} \mathrm{O}_{2}$ in reperfusion injury, little attention has been paid to locating the intracellular sources of iron, although ferritin has been implicated $(19,20)$. To explore the role of cytochrome P-450 enzymes in reperfusion injury, we investigated the effect of three inhibitors of cytochrome P-450 activity on edema formation, microvascular permeability, and lipid peroxidation in a rabbit model of reperfusion lung injury. We also sought to define the basis for the protective effect of these inhibitors by examining their effects on reperfusion-related $\mathrm{O}_{\overline{2}}^{\bar{z}}$ generation and iron mobilization.

\section{Methods}

Lung perfusion technique. Lungs were perfused in a manner similar to that previously reported (18). Male New Zealand white rabbits (Myrtle Farms, Nashville, TN) weighing 2.5-3 kg were maintained on Carnation Rabbit Formula 18 (Carnation Co., Los Angeles, CA) and water ad lib. On the day of the experiment, the rabbits were given 3,000 $\mathrm{U}$ of heparin by ear vein and anesthetized with $25 \mathrm{mg} / \mathrm{kg}$ sodium pentobarbital. The chest was opened and the animal killed by rapid exsanguination from the left ventricle. Right and left parasternal incisions were made along the costal cartilages to remove the sternum and open the chest widely. Stainless steel cannulae were secured in the left atrium and pulmonary artery with umbilical tape. The ligature around the pulmonary artery was also passed around the aorta, preventing loss of perfusate into the systemic circulation. The pulmonary circulation was washed free of blood with $\sim 500 \mathrm{ml}$ of perfusate before recirculating

superoxide anion; ${ }^{\circ} \mathrm{OH}$, hydroxyl radical; $\mathrm{PB}$, piperonyl butoxide; $\mathrm{P}_{\mathrm{pa}}$, pulmonary artery pressure; PVR, pulmonary vascular resistance; $R$, ranitidine; TBA, thiobarbituric acid; $W$, lung weight gain from cumulative transvascular fluid flux. 
flow was established. The perfusate medium was Krebs-Henseleit buffer (21) prepared with deionized water, with $3 \%$ dextran (mol wt 70,000 ) added as an oncotic agent. Perfusate was maintained at a temperature of $37-38^{\circ} \mathrm{C}$ and $\mathrm{pH}$ of $7.35-7.40$.

The perfusion circuit included a perfusate reservoir, roller perfusion pump (Sarns, Inc., Ann Arbor, MI), blood transfusion filter (Cobe Laboratories, Lakewood, CO), and heat exchanger, connected by Tygon tubing. Lung weight changes were continuously recorded as the converse of the weight change of the perfusate reservoir, which was freely suspended from an FT 10D force displacement transducer (Grass Instrument Co., Quincy, MA). The perfusate reservoir was placed below the lowermost portion of the lungs to keep left atrial pressure at zero. The volume of the perfusion system was $250 \mathrm{ml}$.

The lungs were ventilated with $5 \% \mathrm{CO}_{2}$ in air through a tracheostomy using an animal respirator (Harvard Apparatus Co., Inc., The Ealing Corp., S. Natick, MA) delivering a tidal volume of $7 \mathrm{ml} / \mathrm{kg}$ at 18 breaths per min with $2 \mathrm{~cm} \mathrm{H}_{2} \mathrm{O}$-positive end-expiratory pressure. Pulmonary arterial, left atrial, and maximal inspiratory tracheal (referenced from functional residual capacity) pressures were monitored using pressure transducers (P23ID; Gould Statham Instruments, Inc., Hato Rey, PR) connected to the inflow circulation, outflow circulation, and tracheal cannula. Pressure and force transducer measurements were recorded on a four-channel recorder (model 2400S; Gould Statham Instruments, Inc.). Successful preparations with initial pulmonary artery pressures between 8 and $15 \mathrm{mmHg}$ and weight gains at rates of $<0.2 \mathrm{~g} / \mathrm{min}$ were achieved in $>90 \%$ of the rabbit lungs. Lungs can be perfused in this manner for up to $60 \mathrm{~min}$.

Lung perfusion protocols. After surgery, lungs were perfused at 50 $\mathrm{ml} / \mathrm{min}$ for $5 \mathrm{~min}$ to insure integrity of the preparation, as measured by normal pressures and negligible weight gain. Ventilation and perfusion were then stopped and the lungs were covered with moist gauze sponges to prevent desiccation. After a 3-h interval of ischemia, during which the preparation was allowed to equilibrate to room temperature $\left(25^{\circ} \mathrm{C}\right)$, ventilation was reinstated, initially at a tidal volume of 14 $\mathrm{ml} / \mathrm{kg}$ for $30 \mathrm{~s}$ to open atelectatic lung, then at the original tidal volume of $7 \mathrm{ml} / \mathrm{kg}$. Perfusion was then reinstated at $10 \mathrm{ml} / \mathrm{min}$ with increases of $5 \mathrm{ml} / \mathrm{min}$ every $15 \mathrm{~s}$ until a pulmonary arterial pressure of $15 \mathrm{mmHg}$ was achieved. Thereafter, the rate of perfusion was adjusted to maintain pulmonary arterial pressure constant at $15 \mathrm{mmHg}$. Perfusion was continued in this manner for $60 \mathrm{~min}$ to determine the effect of reventilation and reperfusion on lung edema formation monitored by cumulative lung weight gain. Following perfusion, the lungs were quickly dissected free from the thorax. One lung was snap frozen in liquid $\mathrm{N}_{2}$ for measurement of malondialdehyde (MDA) and low molecular weight chelates of iron. The weight of the remaining lung was measured before and after drying for $72 \mathrm{~h}$ at $60^{\circ} \mathrm{C}$ for determination of wet/dry weight ratio.

Pharmacologic interventions. Five normal nonreperfused lung preparations were not subjected to ischemia, but were perfused at constant pressure $(15 \mathrm{mmHg}$ ) for an additional $60 \mathrm{~min}$ after the 5 -min baseline period. Five control reperfused lungs were subjected to ischemia, but were reperfused without treatment. Additional groups of lungs were perfused with one of the following inhibitors of cytochrome P-450 mixed function oxidase activity: five lungs with the suicide substrate 8 -methyoxypsoralen $(22,23)$; five lungs with the classic P-450 inhibitor piperonyl butoxide (23, 24); and five lungs with the $\mathrm{H}_{2}$-receptor blocker cimetidine $(25,26)$. As a control for cimetidine we reperfused four lungs with ranitidine. Ranitidine has three times the $\mathrm{H}_{2}$-receptor blocking activity as cimetidine, but it does not inhibit cytochrome P-450 (25). Methyoxypsoralen ( $50 \mathrm{mg} / \mathrm{kg}$ i.p.) and piperonyl butoxide $(400 \mathrm{mg} / \mathrm{kg}$ i.p.) were injected $1 \mathrm{~h}$ prior to lung perfusion. Cimetidine $(5 \mathrm{mM})$ and ranitidine $(1.5 \mathrm{mM})$ were added to perfusate at the beginning of the baseline perfusion.

Measurement of transvascular flux of ${ }^{125}$ I-albumin. In separate experiments, we assessed transvascular flux of macromolecules during reperfusion, and the response to cytochrome P-450 inhibition. Lungs were subjected to ischemia and reperfused at constant pressure as described above. After $10 \mathrm{~min}$ of reperfusion at a left atrial pressure of zero, $1.5 \mu \mathrm{Ci}$ of ${ }^{125} \mathrm{I}$-human serum albumin ${ }^{125} \mathrm{I}-\mathrm{HSA}^{1}, 8.3 \mathrm{mCi} / \mathrm{g}$ albumin) was added to the reservoir, and left atrial pressure was increased to $10 \mathrm{mmHg}$. $10 \mathrm{~min}$ later, $1.0 \mathrm{ml}$ of pulmonary venous effluent was obtained, weighed, and counted for $1 \mathrm{~min}$ in a gamma counter to determine the number of ${ }^{125} \mathrm{I}-\mathrm{HSA}$ counts in $1.0 \mathrm{~g}$ of circulating perfusate. The reservoir supplying perfusate to the lung was then changed to contain buffer without radioactivity. After lungs were perfused in a nonrecirculating manner for an additional $5 \mathrm{~min}, 1.0 \mathrm{ml}$ of pulmonary venous effluent was obtained and assessed for radioactivity to confirm that minimal ${ }^{125}$ I-HSA counts remained in the vascular space. Perfusion was stopped, and lungs were lavaged by instilling and withdrawing $30 \mathrm{ml}$ of normal saline into the tracheal cannula three times. The lavage fluid was thoroughly mixed, and $1.0 \mathrm{ml}$ was weighed and counted to assess ${ }^{125} \mathrm{I}$-HSA accumulation in the alveolar space. Lungs were then dissected free from the thorax, and a portion of lung from the dorsal surface was weighed and counted to measure ${ }^{125} \mathrm{I}-\mathrm{HSA}$ accumulation in lung tissue. Lavage and lung leak indexes were calculated using the following formulae:

$$
\begin{aligned}
& \text { Lavage leak index }=\frac{{ }^{125} \mathrm{I}-\mathrm{HSA} \text { counts } / \mathrm{g} \text { of lavage fluid }}{{ }^{125} \mathrm{I}-\mathrm{HSA} \text { counts } / \mathrm{g} \text { of perfusate }} \\
& \text { Lung leak index }=\frac{{ }^{125} \mathrm{I} \text {-HSA counts } / \mathrm{g} \text { of lung }}{{ }^{125} \mathrm{I} \text {-HSA counts/g of perfusate }}
\end{aligned}
$$

Three groups were studied: three normal nonreperfused lungs; three untreated reperfused lungs; and three reperfused lungs treated with cimeditine.

Measurement in vivo $O_{\overline{2}}$ production in ventilated and perfused lungs. In another group of experiments, $\mathrm{O}_{\overline{\dot{ }}}$ release into lung perfusate was measured by superoxide dismutase (SOD)-inhibitable reduction of succinylated ferricytochrome $c(18)$. Type VI horse heart ferricytochrome $c$ was partially succinylated by the method of Kuthan et al. (27). $O_{\overline{2}}^{\overline{2}}$ was measured in the perfusate by adding $60 \mu \mathrm{M}$ succinylated ferricytochrome $c$ to the reservoir just before reventilation and reperfusion. Flow was restored to $50 \mathrm{ml} / \mathrm{min}$ and maintained at this rate while 2-ml samples of perfusate were withdrawn from the outflow cannula at timed intervals of $1,2.5,5,7.5$, and $10 \mathrm{~min}$ of perfusion. Samples were centrifuged at $1,000 \mathrm{~g}$ for $10 \mathrm{~min}$ to remove debris, and perfusate absorbance was determined at $550 \mathrm{~nm}$. The change in absorbance between each timed sample and that of $60 \mu \mathrm{M}$ succinylated ferricytochrome $c$ in Krebs-Henseleit buffer was used with an extinction coefficient of $2.1 \times 10^{4} \mathrm{M}^{-1} \mathrm{~cm}^{-1}$ (27) to determine ferricytochrome $c$ reduction. Six groups were studied: four normal nonreperfused lungs; five normal nonreperfused lungs with $\operatorname{SOD}(25,000 \mathrm{U})$ injected into the pulmonary artery before adding ferricytochrome $c$ to perfusate; six untreated reperfused lungs; four reperfused lungs treated with SOD $(25,000 \mathrm{U})$ injected into the pulmonary artery before reperfusion; four reperfused lungs treated with 8-methoxypsoralen; and four reperfused lungs treated with piperonyl butoxide.

Measurement of cytochrome-P450 activity in ventilated and perfused lungs. The activity of cytochrome P-450-mediated $O$-demethylation of $p$-nitroanisole to form $p$-nitrophenol $(28-30)$ was monitored in normal nonischemic ventilated and perfused rabbit lungs as previously reported (30) by adding $350 \mu \mathrm{M} p$-nitroanisole to perfusate. Lungs were then perfused for $60 \mathrm{~min}$ at $50 \mathrm{ml} / \mathrm{min}$. At 10-min intervals 5-ml samples of effluent lung perfusate were obtained and centrifuged at $1,000 \mathrm{~g}$ to remove debris. $1.5 \mathrm{ml}$ of $20 \%$ trichloroacetic acid was added to $3 \mathrm{ml}$ of the supernatant, and the mixture was centrifuged to remove any traces of protein. The supernatant was alkalinized to $\mathrm{pH}$ 12.5 with $10 \mathrm{~N}$ sodium hydroxide. The developed yellow color was read spectrophotometrically at $436 \mathrm{~nm}$ against a blank drawn from the perfusate immediately before addition of $p$-nitroanisole. The concentration of $p$-nitrophenol in timed samples of perfusate was determined by comparing absorbance of samples to a standard curve constructed in Krebs-Henseleit buffer. The rate of change in perfusate concentration of $p$-nitrophenol and lung wet/dry weight ratios were used to calculate the rate of $p$-nitrophenol generation per gram of dry lung during perfusion. Two groups were studied: four normal nonreper- 
fused lungs and four normal nonreperfused lungs treated with $5 \mathrm{mM}$ cimetidine added to perfusate.

Effect of cimetidine on xanthine oxidase activity. The effect of 5 $\mathrm{mM}$ cimetidine on xanthine oxidase activity was studied at $25^{\circ} \mathrm{C}$ in 50 $\mathrm{mM}$ potassium phosphate $(\mathrm{pH} 7.8$ ) containing $0.1 \mathrm{mM}$ EDTA and 30 $\mathrm{mU} / \mathrm{ml}$ xanthine oxidase. The reaction was initiated by adding $50 \mu \mathrm{M}$ xanthine and monitored spectrophotometrically by following conversion of xanthine to urate. Rate of urate formation was calculated from the change in absorbance at $295 \mathrm{~nm}$ using a molar extinction coefficient of $1.1 \times 10^{4} \mathrm{M}^{-1} \mathrm{~cm}^{-1}$.

Measurement of lung malondialdehyde. MDA was determined by the method of Buege and Aust (32). Weighed 250-mg portions of defrosted lungs were homogenized on ice with $2 \mathrm{ml}$ of $1.15 \% \mathrm{KCl}$ and mixed with $4 \mathrm{ml}$ of TBA reagent $(0.375 \%$ thiobarbituric acid and $15 \%$ trichloroacetic acid in $0.25 \mathrm{~N} \mathrm{HCl}$, to which $0.01 \%$ butylated hydroxytoluene was added just before use). After incubation at $100^{\circ} \mathrm{C}$ for 20 min, the absorbance of the supernatant was measured at $532 \mathrm{~nm}$. An extinction coefficient of $1.56 \times 10^{5} \mathrm{M}^{-1} \mathrm{~cm}^{-1}$ (32) and lung wet/dry weight ratios were used to determine micromoles of MDA per gram of dry lung.

Measurement of low molecular weight chelates of iron. Lung tissue concentration of iron as low molecular weight chelates was measured using ferene-S as a detector chelator $(33,34)$. Weighed $250-\mathrm{mg}$ portions of defrosted lungs were homogenized in $2 \mathrm{ml}$ of $0.9 \% \mathrm{NaCl}$ prepared from deionized water and batch-treated with Chelex-100 resin to remove any trace iron contamination. The homogenate was centrifuged at $10,000 \mathrm{~g}$ for $10 \mathrm{~min}$, and the supernatant was filtered through a $0.22-\mu \mathrm{M}$ filter (Millipore/Continental Water Systems, Bedford, MA). An aliquot of 300- $\mu$ l filtrate was mixed with $150 \mu \mathrm{l}$ deionized, Chelex-treated water and $150 \mu \mathrm{l}$ of a solution of $4.4 \%$ thiourea and $2.7 \%$ ascorbate. To this was added $150 \mu \mathrm{l}$ of $40 \%$ trichloroacetic acid. The mixture was vortexed, and then microfuged for $30 \mathrm{~s}$. A $500-\mu \mathrm{l}$ aliquot was mixed with $125 \mu \mathrm{l}$ of ferene solution ( $35 \mathrm{mg}$ sodium ferene in $10 \mathrm{ml}$ of $50 \%$ ammonium acetate in water, wt/vol). After 10 min, absorbance at 594 was compared to that of a blank containing reagents but not tissue sample. Concentration of iron in the sample was determined using a standard curve constructed with $\mathrm{FeSO}_{4}$ and wet to dry weight ratios to express nanomoles of iron per gram of dry lung.

Reagents and pharmaceuticals. ${ }^{125}$ I-HSA was purchased from Syncor Corp. (Memphis, TN). Measurement of radioactivity in supernatants after treatment with $10 \%$ trichloroacetic acid and centrifugation at $2,000 \mathrm{~g}$ for $10 \mathrm{~min}$ demonstrated $<2 \%$ of counts to be unbound. Cimetidine was obtained from Smith, Kline, \& French Laboratories, Smith Kline Corp. (Philadelphia, PA), ranitidine was from Glaxo, Inc. (Research Triangle Park, NC) and 4-nitroanisole was from Aldrich Chemical Co. (Milwaukee, WI). SOD 3,200 U/mg from bovine erythrocytes, xanthine oxidase from buttermilk, and all other reagents were purchased from Sigma Chemical Co. (St. Louis, MO).

Statistical analysis. Pulmonary arterial pressure $\left(\mathrm{P}_{\mathrm{pa}}\right)$, dynamic lung compliance $\left(\mathrm{C}_{\mathrm{dyn}}\right.$, calculated as tidal volume divided by the difference between maximal inspiratory tracheal pressure and positive end-expiratory tracheal pressure), and cumulative lung weight gain from transvascular fluid flux (W) were analyzed by two-way analysis of variance with randomized split block design (35). Rate of $p$-nitrophenol generation was compared in untreated and cimetidine treated lungs using the unpaired Student's $t$ test (35). Measurements of total pulmonary vascular resistance (calculated as pulmonary arterial pressure in $\mathrm{mmHg} \times 80 \mathrm{dyn}^{-1} \cdot \mathrm{s}^{-1} \cdot \mathrm{cm}^{-5}$ divided by liters/min pump flow) and all other parameters were analyzed by one-way analysis of variance (35). Comparisons among groups were performed with Duncan's multiple range test (36). Significance was assumed when $P<0.05$. Values are reported as mean \pm SEM.

\section{Results}

Normal nonischemic lungs perfused for $60 \mathrm{~min}$ demonstrated little evidence of injury. Transvascular fluid flux was negligible
(Fig. 1), and ${ }^{125}$ I-HSA lung and lavage leak indexes were low (Fig. 2, $A$ and $B$ ). At the end of perfusion, dynamic lung compliance $\left(\mathrm{C}_{\mathrm{dyn}}\right)$ was $2.4 \pm 0.2 \mathrm{ml} / \mathrm{cm} \mathrm{H}_{2} \mathrm{O}$, pulmonary arterial pressure $\left(\mathrm{P}_{\mathrm{pa}}\right)$ was $15.0 \pm 0 \mathrm{mmHg}$, and total pulmonary vascular resistance (PVR) was $25.1 \pm 2.9 \times 10^{3} \mathrm{dyn}^{-1} \cdot \mathrm{s}^{-1} \cdot \mathrm{cm}^{-5}$. In contrast, untreated lungs reperfused after $3 \mathrm{~h}$ of ischemia developed visible pulmonary edema, with perfusate filling the tracheal cannulae. Cumulative transvascular fluid flux was markedly increased (Fig. 1). ${ }^{125}$ I-HSA lung and lavage leak indexes were substantially elevated, indicating that vascular permeability to albumin was increased (Fig. 2, $A$ and $B$ ). $\mathrm{C}_{\mathrm{dyn}}$ was significantly lower than in untreated nonreperfused lungs $\left(1.2 \pm 0.1 \mathrm{ml} / \mathrm{cm} \mathrm{H}_{2} \mathrm{O}, P<0.01\right)$, but $\mathrm{P}_{\mathrm{pa}}(15.1 \pm 0.1 \mathrm{mmHg})$ and PVR $\left(20.3 \pm 3.0 \times 10^{3} \mathrm{dyn}^{-1} \cdot \mathrm{s}^{-1} \cdot \mathrm{cm}^{-5}\right)$ were not different than in nonreperfused lungs.

Cytochrome P-450 inhibitors strikingly protected from reperfusion injury. 8-methoxypsoralen (8-MP), piperonyl butoxide (PB), or cimetidine (C) markedly decreased cumulative transvascular fluid flux in reperfused ischemic lungs (Fig. 1) and prevented development of visible pulmonary edema. Cimetidine also prevented the reperfusion-related increase in vascular permeability for ${ }^{125}$ I-HSA (Fig. $2, A$ and $B$ ). P-450 inhibitors significantly improved lung compliance compared to untreated reperfused lungs $(1.7 \pm 0.1$ for $8-\mathrm{MP}$ and $1.7 \pm 0.1$ for $\mathrm{PB}, 1.6 \pm 0.1$ for $\mathrm{C}$ vs. $1.2 \pm 0.1 \mathrm{ml} / \mathrm{cm}_{2} \mathrm{O}$ for untreated reperfused lungs; all $P<0.05$ compared to untreated reperfused lungs). $\mathrm{P}_{\mathrm{pa}}$ in lungs treated with 8-methoxypsoralen or piperonyl butoxide was not different from $P_{p a}$ in untreated reperfused lungs $(14.2 \pm 0.9 \mathrm{mmHg}$ for $8-\mathrm{MP} ; 15.1 \pm 0$ for $\mathrm{PB}$ ). However, $\mathrm{P}_{\mathrm{pa}}$ in cimetidine-treated reperfused lungs was lower $(12 \pm 0.5 \mathrm{mmHg}, P, 0.06)$ because cimetidine decreased PVR during reperfusion $\left(8.6 \pm 1.4 \times 10^{3} \mathrm{dyn} \cdot \mathrm{s} \cdot \mathrm{cm}^{-5}\right.$ for cimetidine vs. $20.3 \pm 3$ for untreated reperfused lungs, $P<0.05$ ). Flow

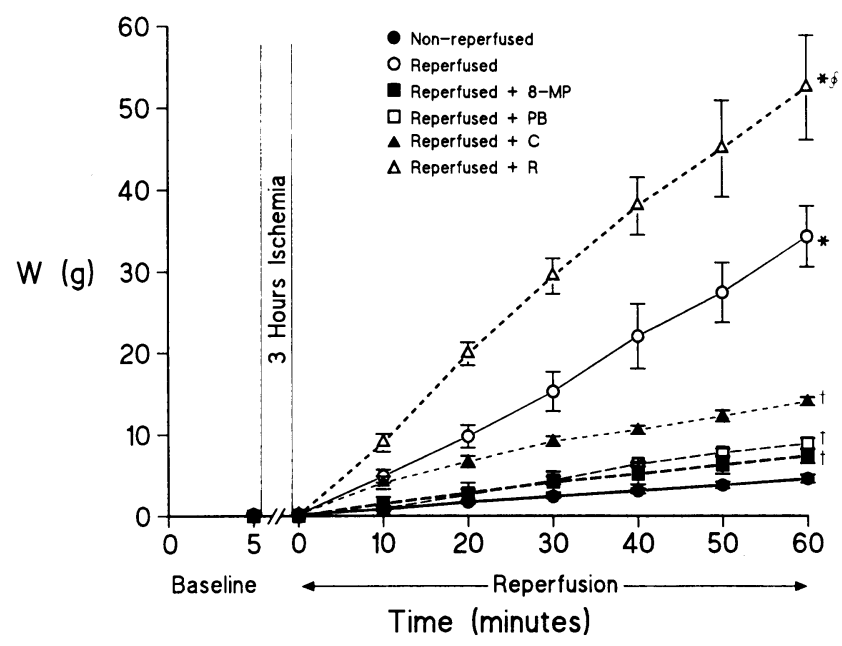

Figure 1. Cytochrome P-450 inhibitors prevent transvascular fluid flux $(W)$ from reperfusion lung injury. Compared to nonreperfused normal lungs, untreated reperfused lungs develop profound lung edema from transvascular fluid flux. Treatment with the cytochrome P-450 inhibitors 8-methoxypsoralen (8-MP), piperonyl butoxide (PB), or cimetidine (C) markedly reduce transvascular fluid flux during reperfusion. In contrast, ranitidine ( $\mathrm{R})$, an $\mathrm{H}_{2}$-receptor blocker which does not inhibit $\mathrm{P}-450$, fails to attenuate reperfusion injury. ${ }^{*} P$ $<0.001$ compared to nonreperfused; ${ }^{\dagger} P<0.001$ compared to reperfused; ${ }^{\S} P<0.001$ compared to reperfused $+C$. 

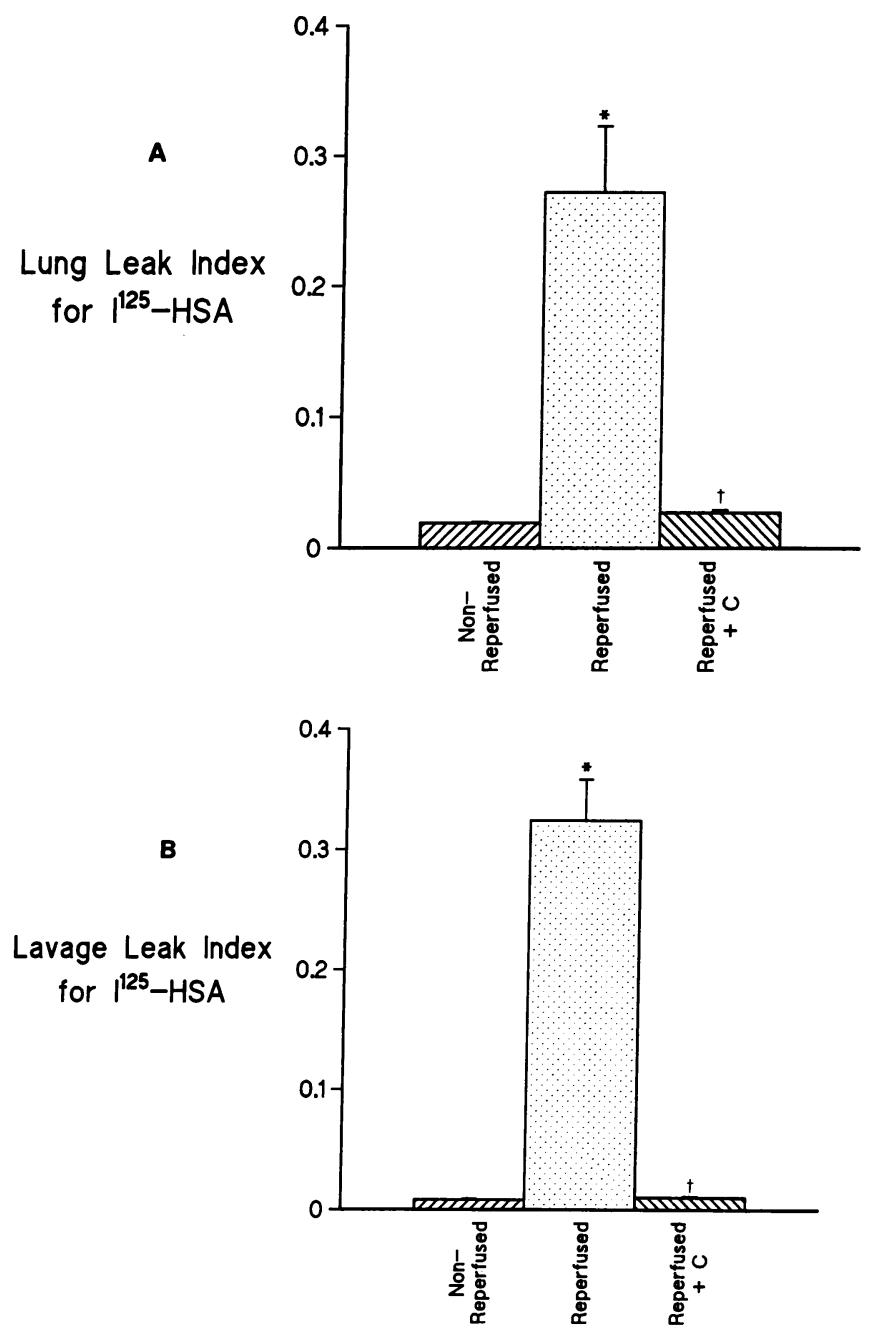

Figure 2. Cimetidine prevents the increase in microvascular permeability caused by reperfusion. Reperfusion of ischemic lung markedly increases microvascular permeability measured by $\mathrm{I}^{125}$-HSA lung $(A)$ and lavage $(B)$ leak indexes. Inhibition of cytochrome $P-450$ with cimetidine $(C)$ prevents increased permeability from reperfusion. ${ }^{*} P$ $<0.001$ compared to nonreperfused; ${ }^{\dagger} P<0.001$ compared to reperfused.

during reperfusion was at maximum for our pump (140 ml/ $\mathrm{min}$ ) in 4 of 5 cimetidine-treated lungs, and mean pump flow after 60 min was significantly higher in cimetidine treated than in untreated reperfused lungs $(126 \pm 15$ vs. $71 \pm 18 \mathrm{ml} / \mathrm{min}, P$ $<0.05$ ). PVR in reperfused lungs treated with 8-methoxypsoralen $\left(15.3 \pm 4.5 \times 10^{3} \mathrm{dyn}^{-1} \cdot \mathrm{s}^{-1} \cdot \mathrm{cm}^{-5}\right)$ or piperonyl butoxide $\left(22.4 \pm 2.2 \mathrm{dyn}^{-1} \cdot \mathrm{s}^{-1} \cdot \mathrm{cm}^{-5}\right)$ was not significantly different from that in untreated reperfused lungs.

To confirm that cytochrome $\mathrm{P}-450$ was being inhibited in this model, we studied the effect of cimetidine on P-450-mediated $O$-demethylation of $p$-nitroanisole to $p$-nitrophenol. Whereas untreated nonreperfused rabbit lungs produced $41 \pm 7$ pmol of $p$-nitrophenol/g of dry lung/min, lungs perfused with $5 \mathrm{mM}$ cimetidine generated only $16 \pm 4 \mathrm{pmol} / \mathrm{g}$ dry lung/min $(P<0.01)$.

In contrast to the protection provided by cimetidine, ranitidine $(R)$ failed to prevent pulmonary edema during reperfusion. Transvascular fluid flux in ranitidine-treated reperfused lungs (Fig. 1) was even higher than in untreated reperfused controls $(P<0.05) . \mathrm{C}_{\mathrm{dyn}}\left(1.4 \pm 0 \mathrm{ml} / \mathrm{cm} \mathrm{H}_{2} \mathrm{O}\right), \mathrm{P}_{\mathrm{pa}}(14.8 \pm 0.1$ $\mathrm{mmHg})$, and PVR $\left(17.2 \pm 3.3 \times 10^{3} \mathrm{dyn}^{-1} \cdot \mathrm{s}^{-1} \cdot \mathrm{cm}^{-5}\right)$ were not different from untreated reperfused lungs.

Biochemical evidence of a protective effect of cytochrome P-450 inhibition was obtained by measuring lung MDA as a marker of membrane lipid peroxidation. Lung content of MDA was increased over $60 \%$ in untreated reperfused lungs (Fig. 3). Treatment with 8-methoxypsoralen, piperonyl butoxide, or cimetidine prevented the increase in lung MDA caused by reperfusion. In fact, the MDA content in these treated lungs was the same as in normal nonreperfused lungs. Ranitidine, however, did not prevent the increase in MDA caused by reperfusion. This suggests that cytochrome P-450 inhibitors protect the lung from reperfusion by decreasing oxidant injury.

The mechanism by which cytochrome P-450 inhibitors decrease oxidant injury was investigated by measuring the in vivo $\mathrm{O}_{\overline{2}}^{\overline{2}}$ release into lung perfusate and the content of low molecular weight iron chelates in lung tissue. Because xanthine oxidase is likely responsible for a portion of the enhanced

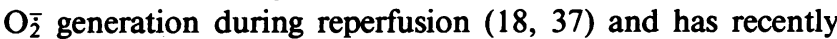
been demonstrated to be present in ischemic reperfused rabbit lung (37), we initially studied the effect of cimetidine on xanthine oxidase activity in vitro. Xanthine oxidase generated $0.6 \mu \mathrm{mol}$ of urate per min without cimetidine and $0.5 \mu \mathrm{mol}$ per min in the presence of $5 \mathrm{mM}$ cimetidine. Thus, cimetidine does not appear to substantially decrease the activity of xanthine oxidase in vitro.

Fig. 4 shows the results of in vivo $\mathrm{O}_{\overline{2}}^{\bar{z}}$ generation measured by reduction of succinylated ferricytochrome $c$ in perfusate over $10 \mathrm{~min}$. Reduction occurred in uninjured nonreperfused lungs, but did not increase substantially over time and was inhibited only slightly by SOD. In contrast, reduction of succinylated ferricytochrome $c$ was significantly higher in untreated reperfused lungs and was inhibited by SOD. Treatment

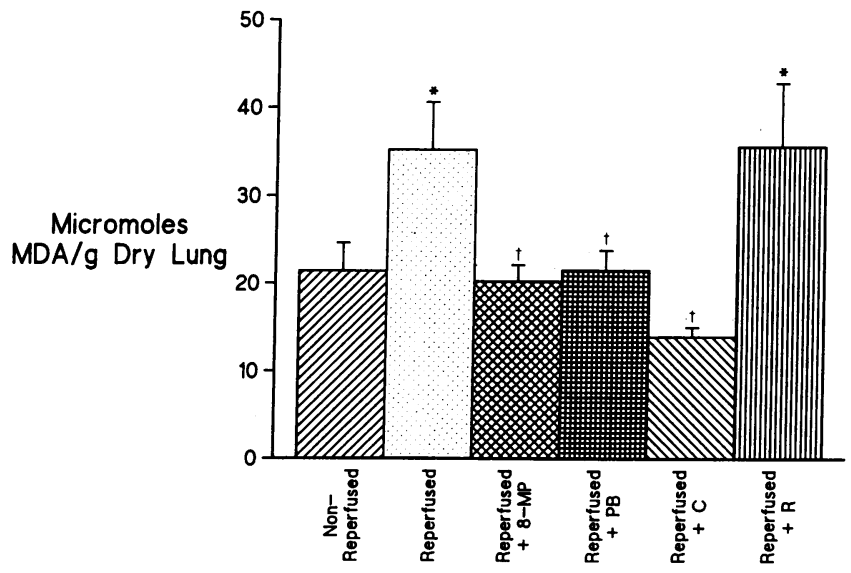

Figure 3. Cytochrome P-450 inhibitors prevent the increase in lung lipid peroxidation caused by reperfusion. Reperfusion of ischemic lung causes a marked increase in lung content of malondialdehyde (MDA). Treatment with the cytochrome P-450 inhibitors 8-methoxypsoralen (8-MP), piperonyl butoxide $(P B)$, or cimetidine $(C)$ prevents accumulation of MDA during reperfusion. In contrast, ranitidine $(R)$, an $\mathrm{H}_{2}$-receptor blocker which does not inhibit $\mathrm{P}-450$, fails to prevent MDA accumulation. ${ }^{*} P<0.001$ compared to nonreperfused; ${ }^{\dagger} P<0.001$ compared to reperfused. 


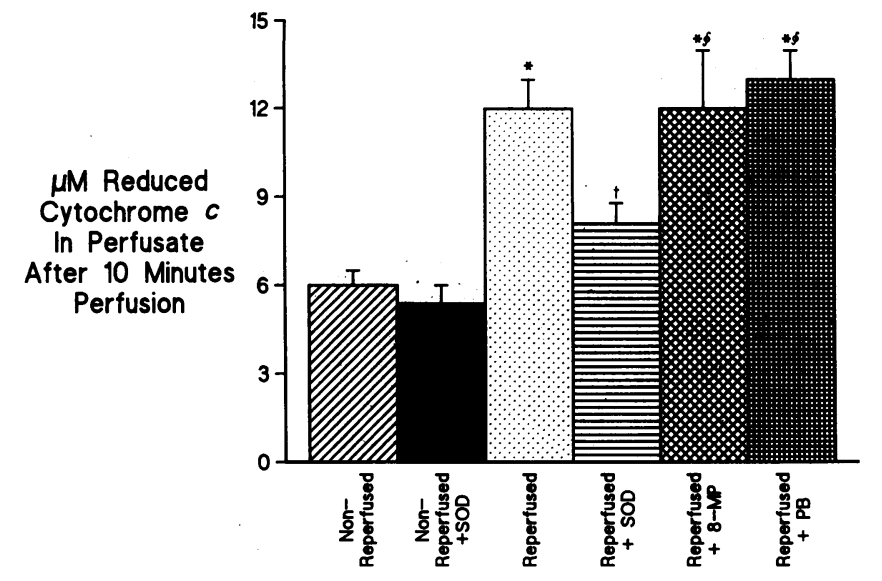

Figure 4. Cytochrome P-450 inhibitors do not prevent lung generation of $\mathrm{O}_{\overline{2}}$ during reperfusion. Reperfusion of ischemic lung markedly increases reduction of succinylated ferricytochrome $c$ in lung perfusate. Injection of $25,000 \mathrm{U}$ SOD into the pulmonary artery before reperfusion prevents the increase in cytochrome $c$ reduction. In contrast, the P-450 inhibitors 8-methoxypsoralen (8-MP) and piperonyl butoxide $(P B)$ have no effect on enhanced cytochrome $c$ reduction during reperfusion. ${ }^{*} P<0.001$ compared to nonreperfused; ${ }^{\dagger} P$ $<0.01$ compared to reperfused; ${ }^{\S} P<0.01$ compared to reperfused + SOD.

with 8-methoxysporalen or piperonyl butoxide failed to reduce cytochrome $c$ reduction during reperfusion. The effect of cimetidine on reduction of succinylated ferricytochrome $c$ reduction could not be studied in perfused lungs because $5 \mathrm{mM}$ cimetidine was found to cause a slow progressive decrease in cytochrome $c$ absorbance in vitro.

Because iron plays an important role in the initiation (38, 39 ) and progression (38-40) of lipid peroxidation, we determined lung tissue levels of non-protein-bound iron, measured as low molecular weight chelates. Reperfused ischemic lungs contained over $80 \%$ more low molecular weight iron chelates than did control groups (Fig. 5). Treatment with 8-methoxysporalen, piperonyl butoxide, or cimetidine prevented the increase in tissue levels of low molecular weight iron chelates in ischemic reperfused lung but ranitidine did not (Fig. 5).

\section{Discussion}

In this study, inhibitors of cytochrome $\mathrm{P}-450$ provided striking protection against reperfusion lung injury. In our model, the restoration of ventilation and perfusion to lungs after ischemia resulted in acute lung injury characterized by increased lung weight gain, albumin permeability, and thiobarbituric acid reactive products. The cytochrome $\mathrm{P}-450$ inhibitors 8 -methoxypsoralen, piperonyl butoxide, or cimetidine markedly attenuated these reperfusion-related pathophysiological and biochemical changes. To our knowledge, this is the first study to demonstrate a central role of cytochrome P-450 enzymes in reperfusion injury.

Because we perfused at a constant pressure, it is unlikely that the decrease in transvascular fluid flux observed in reperfused lungs treated with 8-methoxypsoralen or piperonyl butoxide (Fig. 1) can be explained by differences in microvascular pressure. PVR in lungs treated with 8-methoxypsoralen or piperonyl butoxide was not different from that in untreated

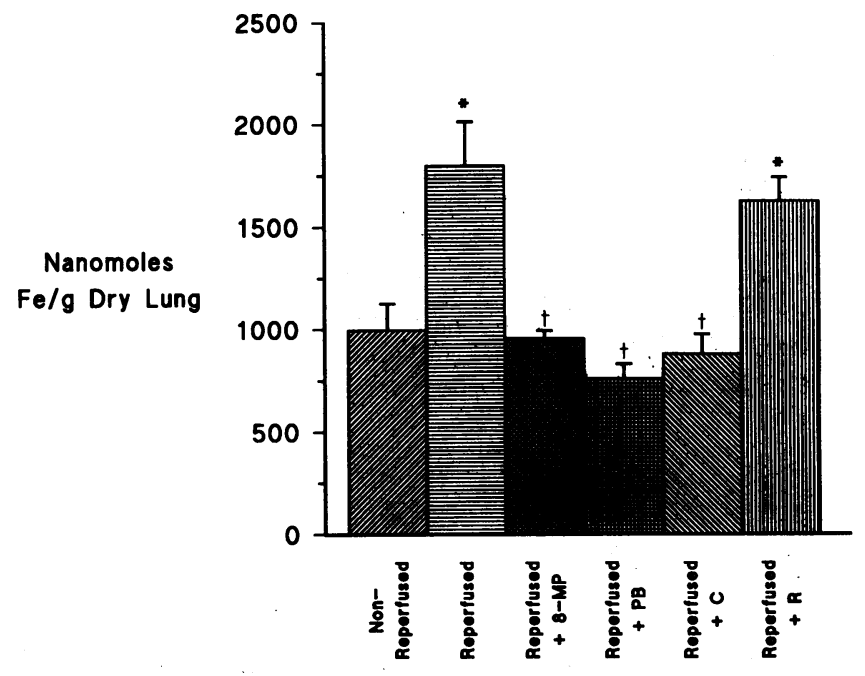

Figure 5. Cytochrome P-450 inhibitors prevent the increase in lung low molecular weight iron chelates that occur during reperfusion. Reperfusion of ischemic lung results in an increase in tissue levels of low molecular weight iron chelates. Treatment with the cytochrome P-450 inhibitors 8-methoxypsoralen (8-MP), piperonyl butoxide $(P B)$, or cimetidine $(C)$ prevents the increase. In contrast, ranitidine $(R)$, an $\mathrm{H}_{2}$-receptor blocker which does not inhibit P-450, fails to block the rise in iron chelates during reperfusion. ${ }^{*} P<0.01$ compared to nonreperfused; ${ }^{\dagger} P<0.01$ compared to reperfused.

reperfused lungs. PVR in cimetidine-treated lungs was lower than in untreated reperfused lungs and pump flow was significantly higher, suggesting that substantially more of the microvascular bed was perfused in cimetidine-treated than in untreated reperfused lungs. Despite reperfusion of a much greater vascular surface area, cumulative weight gain in cimetidinetreated reperfused lungs was only $40 \%$ of that observed in untreated reperfused lungs. In addition, cimetidine prevented the dramatic increase in ${ }^{125} \mathrm{I}$-albumin flux, suggesting that its protective effects, similar to 8-methoxypsoralen and piperonyl butoxide, were due to prevention of the increased microvascular permeability during reperfusion.

We used three different inhibitors of cytochrome P-450 in these studies to increase the specificity of our observations. 8-methoxypsoralen functions as a suicide substrate. It forms a reactive metabolite that binds to microsomal protein and inactivates cytochrome P-450 enzymes $(22,23)$. Piperonyl butoxide is metabolized to a reactive intermediate that binds to cytochrome P-450 and inhibits further microsomal metabolism $(23,24)$. The $\mathrm{H}_{2}$-receptor blocker cimetidine disrupts microsomal metabolism by binding to cytochrome P-450 with high affinity $(25,26)$. Both the imidazole ring and cyano group of cimetidine interact with the P-450 hemin iron (26). This effect of cimetidine is specific for $\mathrm{P}-450$ as it does not interact with other heme enzymes (41). In contrast, the $\mathrm{H}_{2}$-receptor blocker ranitidine inhibits cytochrome $\mathrm{P}-450$ either weakly or not at all $(25,26)$. Because 8-methoxypsoralen, piperonyl butoxide, and cimetidine are structurally dissimilar and inhibit cytochrome $\mathrm{P}-450$ by different mechanisms, the protection which these inhibitors have against reperfusion injury is most likely to be explained by P-450 inhibition. However, we cannot rule out that these inhibitors might protect through other biochemical actions that have not yet been described. 
Reperfusion lung injury is oxidant mediated (18). Since cytochrome P-450 inhibitors prevented the increase of thiobarbituric acid-reactive products in ischemic lung following reperfusion, it is likely that they protect by interfering with biochemical events that lead to oxidant injury. Cytochrome P-450 may participate in these biochemical events by generating reactive oxygen species during microsomal electron transport or by providing an intracellular source of iron. $\mathrm{Cy}$ tochrome P-450 has been hypothesized as a major source of enhanced $\mathrm{O}_{\overline{2}}$ generation by lungs exposed to hyperoxia and other forms of oxidant stress $(12,13,42)$. As the availability of NADPH is rate limiting for cytochrome P-450 activity in vivo (43), a buildup of reducing equivalents in ischemic tissue (44, 45) followed by the sudden availability of $\mathrm{O}_{\overline{2}}^{\overline{2}}$ during reventilation and reperfusion might create favorable conditions for auto-oxidation of $\mathrm{P}-450$ enzyme complexes leading to the generation of $\mathrm{O}_{\overline{2}}$. If so, cytochrome $\mathrm{P}-450$ inhibition might decrease reperfusion injury by blocking generation of $\mathrm{O}_{\overline{2}}$, the initial reactive oxygen species necessary for the generation of $\mathrm{OH}$ via the Fenton reaction to occur or for the initiation of lipid peroxidation. We were able to demonstrate enhanced reduction of succinylated ferricytochrome $c$ in the perfusate of ischemic lungs during reperfusion (Fig. 4). This increased reduction of cytochrome $c$ could be inhibited by SOD indicating $\mathrm{O}_{\overline{2}}$ generation. Despite protecting from injury, the cytochrome P-450 inhibitors 8-methoxypsoralen and piperonyl butoxide failed to decrease cytochrome $c$ reduction during reperfusion. Thus, cytochrome P-450 enzymes are unlikely to be major sources of $\mathrm{O}_{\overline{2}}$ generation during reperfusion of ischemic lung.

A second role for cytochrome $\mathrm{P}-450$ in reperfusion injury of the lung is to provide a biologic source of iron. The iron chelator deferoxamine, but not iron-saturated deferoxamine, protects from reperfusion in our model, suggesting that iron is necessary for injury to occur (18). We speculate that P-450 inhibitors bind near the active site of the enzyme, rendering the heme iron unavailable. The inhibitors do not affect other heme-containing enzymes (41). Gutteridge has recently demonstrated that $\mathrm{H}_{2} \mathrm{O}_{2}$ and organic hydroperoxides can oxidatively degrade hemoglobin and promote the release of iron from the heme chelate (46). Likewise, if the heme chelate of cytochrome P-450 was altered or destroyed, heme iron in $\mathrm{P}-450$ enzymes might potentially serve as another iron source in addition to ferritin $(47,48)$ for the enhanced formation of low molecular weight iron chelates during ischemia and reperfusion $(49,50)$. As shown in Fig. 5, tissue levels of low molecular weight iron chelates are increased in ischemic reperfused lung in a similar magnitude as reported in ischemic reperfused brain (17) and heart (49). Furthermore, the increase iron is prevented by 8-methoxypsoralen, piperonyl butoxide, or cimetidine. Thus, cytochrome $\mathrm{P}-450$ inhibitors completely prevent the increase in non-protein-bound low molecular weight iron chelates. One possible mechanism is that the inhibitors may stabilize and protect the enzyme from assault by peroxides generated during reperfusion, thereby decreasing destruction of the heme chelate and release of its iron.

What role may the iron released from cytochrome P-450 play in reperfusion injury? First, cytochrome P-450 iron can generate $\mathrm{OH}$ by functioning as a Fenton catalyst (7). Generation of ${ }^{\circ} \mathrm{OH}$ can in turn oxidatively injure proteins, carbohydrates, purines, and other water-soluble biological molecules $(50,51)$. It has been thought that iron is made catalytically active in biological systems by forming chelates with low molecular weight substances such as ATP, ADP, citrate, or malate (51), which leave at least one coordination site open and thus enhance iron reactivity (52). However, recently it has been proposed that iron binds directly to a multitude of biological molecules, generating ${ }^{\circ} \mathrm{OH}$ not in free solution but directly at the target molecule, causing "site-specific" oxidative modification $(51,53)$. The protective effect of dimethylthiourea, an $\mathrm{OH}$ scavenger, in our model supports a role for ${ }^{\circ} \mathrm{OH}$ in reperfusion injury.

Second, cytochrome P-450 iron may play a role in propagation of lipid peroxidation by mechanisms which do not involve ${ }^{\circ} \mathrm{OH}(54,55)$. Propagation reactions account for $>90 \%$ of the products formed during lipid peroxidation (56). Iron from cytochrome P-450 is an excellent propagating agent which is actually superior to EDTA-Fe ${ }^{+2}$ on a per-mole basis (56). In this investigation, the observation that P-450 inhibitors block lipid peroxidation provides support for a role of cytochrome $\mathrm{P}-450$ iron in mediating lipid peroxidation.

The exact biochemical mechanisms by which cytochrome P-450 mediates reperfusion injury remain to be determined. Nevertheless, our results suggest that cytochrome P-450 enzymes play an important role in reperfusion injury to the lung. This mechanism may also be relevant to reperfusion injury in other organs with abundant cytochrome P-450 enzymes, such as the liver and kidney (10). The possibility that cimetidine, as a P-450 inhibitor, can prevent reperfusion injury has potential clinical implications.

\section{Acknowledgments}

The authors gratefully acknowledge the assistance of Mrs. Linda Crisp in preparation of this manuscript.

This work was supported by grants HL-40665, HL-01302, and HL-37615 from the National Institutes of Health, and hy Merit Review research funds from the Veterans Administration.

\section{References}

1. McCord, J. M. 1985. Oxygen-derived free radicals in post-ischemic tissue injury. N. Engl. J. Med. 312:159-163.

2. Downey, J. M., T. Miura; L. J. Eddy, D. E. Chambers, T. Mellert, D. J. Hearse, and D. M. Yellon. 1987. Xanthine oxidase is not a source of free radicals in the ischemic rabbit heart. J. Mol. Cell. Cardiol. 19:1053-1060.

3. Eddy, L. J., J. R. Stewart, H. P. Jones, T. D. Engerson, J. M. McCord, and J. M. Downey. 1987. Free radical-producing enzyme, xanthine oxidase, is undetectable in human hearts. Am. J. Physiol. 253 (Heart Circ. Physiol. 22):H709-H711.

4. Podzuweit, T., W. Braun, A. Muller, and W. Schaper. 1987. Arrhythmias and infarction in the ischemic pig heart are not mediated by xanthine oxidase-derived free oxygen radicals. Basic Res. Cardiol. 82:493-505.

5. de Groot, H., and A. Littauer. 1988. Reoxygenation injury in isolated hepatocytes: cell death precedes conversion of xanthine dehydrogenase to xanthine oxidase. Biochem. Biophys. Res. Commun. 155:278-282.

6. Kuthan, H., H. Tsuji, H. Graf, V. Ullrich, J. Werringloer, and R. W. Estabrook. 1978. Generation of superoxide anion as a source of hydrogen peroxide in a reconstituted monooxygenase system. FEBS (Fed. Eur. Biochem. Soc.) Lett. 91:343-345.

7. White, R. E., and M. J. Coon. 1980. Oxygen activation by cytochrome P-450. Annu. Rev. Biochem. 49:315-356. 
8. Aust, S. D., D. L. Roerig, and T. C. Pederson. 1972. Evidence for superoxide generation by NADPH-cytochrome $\mathrm{C}$ reductase of rat liver microsomes. Biochem. Biophys. Res. Commun. 47:1133-1137.

9. Grover, T. A., and L. H. Piette. 1981. Influence of flavin addition and removal on the formation of superoxide by NADPH-cytochrome P-450 reductase: a spin-trap study. Arch. Biochem. Biophys. 212:105-114.

10. Schwab, G. E., and E. F. Johnson. 1987. Enzymology of rabbit cytochromes P-450. In Mammalian Cytochromes P-450. Vol. I. P. Guengerich, editor. CRC Press, Inc., Boca Raton, FL. 55-105.

11. Chance, B., H. Sies, and A. Boveris. 1979. Hydroperoxide metabolism in mammalian organs. Physiol. Rev. 59:527-605.

12. Turrens, J. F., B. A. Freeman, and J. D. Crapo. 1982. Hyperoxia increases $\mathrm{H}_{2} \mathrm{O}_{2}$ release by lung mitochondria and microsomes. Arch. Biochem. Biophys. 217:411-421.

13. Tindberg, N., and M. Ingelman-Sundberg. 1989. Cytochrome P-450 and oxygen toxicity. Oxygen-dependent induction of ethanolinducible cytochrome P-450 (IIE1) in rat liver and lung. Biochemistry. 28:4499-4504.

14. Ambrosio, G., J. L. Zweir, W. E. Jacobus, and J. T. Flaherty. 1987. Improvement of postischemic myocardial function and metabolism induced by administration of deferoxamine at the time of reflow: the role of iron in the pathogenesis of reperfusion injury. Circulation. 76:906-915.

15. Hernandez, L. A., M. B. Grisham, and D. N. Granger. 1987. A role for iron in oxidant-mediated ischemic injury to intestinal microvasculature. Am. J. Physiol. 253:649-653.

16. Yoon, J. O., M. C. Im, P. N. Manson, G. B. Bulkley, and J. E. Hoopes. 1989. The role of metal irons in ischemia/reperfusion injury in skin flaps. J. Surg. Res. 46:163-165.

17. Nayini, N. R., B. C. White, S. D. Aust, R. R. Huang, R. J. Indrieri, A. T. Evans, H. Bialek, W. A. Jacobs, and J. Komara. 1985. Postischemic iron delocalization and malondialdehyde production in the brain following prolonged cardiac arrest. J. Free Radicals Biol. \& Med. 1:111-115.

18. Kennedy, T. P., N. V. Rao, C. Hopkins, L. Pennington, E Tolley, and J. R. Hoidal. 1989. Role of reactive oxygen species in reperfusion injury of the rabbit lung. J. Clin. Invest. 83:1326-1335.

19. Bolann, B. J., and R. J. Blvak. 1987. Release of iron from ferritin by xanthine oxidase. Role of the superoxide radical. Biochem. J. 243:55-59.

20. Thomas, C. E., L. A. Morehouse, and S. D. Aust. 1985. Ferritin and superoxide-dependent lipid peroxidation. J. Biol. Chem. 260:3275-3280.

21. Krebs, H. A., and K. Henseleit. 1982. Untersuchungen uber die harustoffbildung im tierkorper. Hoppe-Seyler's Z. Physiol. Chem. 210:33-66.

22. Fouin-Fortunet, H., M. Tinel, V. Descatoire, P. Letteron, D. Larrey, J. Geneve, and D. Pessayre. 1986. Inactivation of cytochrome P-450 by the drug methoxsalen. J. Pharmacol. Exp. Ther. 236:237247.

23. Mays, D. C., J. B. Hilliard, D. D. Wong, and N. Gerber. 1989. Activation of 8-methoxypsoralen by cytochrome P-450. Enzyme kinetics of covalent binding and influence of inhibitors and inducers of drug metabolism. Biochem. Pharmacol. 38:1647-1655.

24. James, R. C., and R. D. Harbison. 1982. Hepatic glutathione and hepatotoxicity. Effects of cytochrome P-450 complexing compounds SKF 525-A, L- $\alpha$ acetylmethadol (LAAM), norLAAM, and piperonyl butoxide. Biochem. Pharmacol. 31:1829-1835.

25. Speeg, K. V., Jr., R. V. Patwardhan, G. R. Avant, M. C. Mitchell, and S. Schenker. 1982. Inhibition of microsomal drug metabolism by histamine $\mathrm{H}_{2}$-receptor antagonists studied in vivo and in vitro in rodents. Gastroenterology. 82:89-96.

26. Rendic, S., F. Kajfez, and H.-H. Ruf. 1983. Characterization of cimetidine, ranitidine, and related structures' interaction with cytochrome P-450. Drug Metab. Dispos. 11:137-142.
27. Kuthan, H., V. Ullrich, and R. W. Estabrook. 1982. A quantitative test for superoxide radicals produced in biological systems. Biochem. J. 203:551-558.

28. Itakura, N., A. B. Fisher, and R. G. Thurman. 1977. Cytochrome P-450 linked p-nitroanisole O-demethylation in the perfused lung. J. Appl. Physiol. Respir. Environ. Exercise Physiol. 43:238-245.

29. Fisher, A. B., N. Itakura, C. Dodia, and R. G. Thurman. 1979. Relationship between alveolar $\mathrm{PO}_{2}$ and the rate of $p$-nitroanisole $O$-demethylation by the cytochrome $\mathrm{P}-450$ pathway in isolated rabbit lungs. J. Clin. Invest. 64:770-774.

30. Knoblauch, A., A. Sybert, N. J. Brennan, J. T. Sylvester, and G. H. Gurtner. 1981. Effect of hypoxia and CO on a cytochrome P-450-mediated reaction in rabbit lungs. J. Appl. Physiol. Respir. Environ. Exercise Physiol. 51:1635-1642.

31. Fridovich, I. Xanthine oxidase. In CRC Handbook of Methods for Oxygen Radical Research. R. A. Greenwald, editor. CRC Press, Inc., Boca Raton, FL. 51-53.

32. Buege, J. A., and S. D. Aust. 1978. Microsomal lipid peroxidation. Methods Enzymol. 51:302-310.

33. Artiss, J. D., S. Vinogrador, and B. Zak. 1981. Spectrophotometric study of several sensitive reagents for serum iron. Clin. Biochem. 14:311-315.

34. Sadrzadeh, S. M. H., and J. W. Eaton. 1988. Hemoglobin-mediated oxidant damage to the central nervous system requires endogenous ascorbate. J. Clin. Invest. 82:1510-1515.

35. Snedecor, G. E., and W. G. Cochran. Statistical Methods. 7th ed. Iowa State University Press, Ames, IA. 256-257.

36. Duncan, D. B. 1975. $t$-tests and intervals for comparison suggested by the data. Biometrics. 31:339-359.

37. Horgan, M. J., H. Lum, and A. B. Malik. 1989. Pulmonary edema after pulmonary artery occlusion and reperfusion. Am. Rev. Respir. Dis. 140:1421-1428.

38. Aust, S. D., and B. A. Svingen. 1982. The role of iron in enzymatic lipid peroxidation. In Free Radicals in Biology. Vol. 5. W. A. Pryor, editor. Academic Press, Inc., New York. 1-28.

39. Minotti, G., and S. D. Aust. 1987. The requirement for ferric in the initiation of lipid peroxidation by ferrous and hydrogen peroxide. J. Biol. Chem. 262:1098-1104.

40. Svingen, B. A., J. A. Buege, F. O. O'Neal, and S. D. Aust. 1979. The mechanism of NADPH-dependent lipid peroxidation. The propagation of lipid peroxidation. J. Biol. Chem. 254:5892-5899.

41. Baird, M. B., G. T. Steir, and C. D. Slade-Pacini. 1987. Lack of inhibition of mouse catalase activity by cimetidine: an argument against a relevant general effect of cimetidine upon heme metabolic pathways. Biochem. Pharmacol. 36:4366-4369.

42. Grisham, M. B., and D. N. Granger. 1989. Metabolic sources of reactive oxygen metabolites during oxidant stress and ischemia with reperfusion. Clin. Chest Med. 10:71-81.

43. Thurman, R. G., S. A. Belinsky, and F. C. Kauffman. 1987 Regulation of mono-oxygenation in intact cells. In Mammalian Cytochromes P-450. Vol. II. F. P. Guengerich, editor. CRC Press, Inc., Boca Raton, FL. 131-152.

44. Ginsberg, M. D., M. Reivich, and S. Frank. 1976. Pyridine nucleotide redox state and blood flow in the cerebral cortex following middle cerebral artery occlusion in the cat. Stroke. 7:125-131.

45. Fisher, A. B., and H. J. Forman. 1985. Oxygen utilization and toxicity in the lungs. In Handbook of Physiology. Section 3, The Respiratory System. Circulation and Nonrespiratory Functions. Vol. I. A. P. Fishman and A. B. Fisher, editors. American Physiological Society, Bethesda, MD. 231-254.

46. Gutteridge, J. M. C. 1986. Iron promoters of the Fenton reaction and lipid peroxidation can be released from haemoglobin by peroxides. FEBS (Fed. Eur. Biochem. Soc.) Lett. 210:291-295.

47. Bolann, B. J., and R. J. Blvak. 1987. Release of iron from ferritin by xanthine oxidase. Role of the superoxide radical. Biochem. J. 243:55-59. 
48. Thomas, C. E., L. A. Morehouse, and S. D. Aust. 1985. Ferritin and superoxide-dependent lipid peroxidation. J. Biol. Chem. 260:3275-3280.

49. Holt, S., M. Gunderson, K. Joyce, N. R. Nayini, G. F. Eyster, A. M. Garitano, C. Zonia, G. S. Krause, S. D. Aust, and B. C. White. 1986. Myocardial tissue iron delocalization and evidence for lipid peroxidation after two hours of ischemia. Ann. Emerg. Med. 15:11551159.

50. Halliwell, B., and J. M. C. Gutteridge. 1984. Oxygen toxicity, oxygen radicals, transitions metals and disease. Biochem. J. 219:1-14.

51. Halliwell, B., and J. M. C. Gutteridge. 1986. Oxygen free radicals and iron in relation to biology and medicine: some problems and concepts. Arch. Biochem. Biophys. 246:501-514.

52. Graf, E., J. R. Mahoney, R. G. Bryant, and J. W. Eaton. 1984.
Iron-catalyzed hydroxyl radical formation. Stringent requirement for free iron coordination site. J. Biol. Chem. 259:3620-3624.

53. Chevion, M. 1988. A site-specific mechanism for free radical induced biological damage: the essential role of redox-active transition metals. J. Free Radicals \& Biol. Med. 5:27-37.

54. Braughler, J. M., L. A. Duncan, and R. L. Chase. 1986. The involvement of iron in lipid peroxidation. J. Biol. Chem. 261:1028210289.

55. Minotti, G., and S. D. Aust. 1987. The requirement for ferric in the initiation of lipid peroxidation by ferrous and hydrogen peroxide. J. Biol. Chem. 262:1098-1104.

56. Svingen, B. A., J. A. Buege, F. O. O'Neal, and S. D. Aust. 1978. The mechanism of NADPH-dependent lipid peroxidation: the propagation of lipid peroxidation. J. Biol. Chem. 254:5892-5899. 